\title{
The Effect of Supply Chain Quality Integration on Supply Chain Management Practice to Achieve Supply Chain Performance
}

\author{
Monika Kussetya Ciptani \\ monique@president.ac.id \\ Accounting Program Study, Faculty of Business \\ Universitas Presiden, Cikarang, Indonesia \\ Yunica Wahyu Dewantari \\ yunicadewantari@gmail.com \\ Accounting Program Study, Faculty of Business \\ Universitas Presiden, Cikarang, Indonesia
}

\begin{abstract}
In manufacturing company, quality of product could become their competitive advantage to compete in the market. To achieve good quality of products and activities, company need to have system or strategy to manage their supply chain activity and make it more effective and efficient flow of production and improve the quality of information sharing, production time, and products, so the company can improve their performance. This study conducted to find out the mediating effect of supply chain quality integration on supply chain management practices to achieve performance. Researcher was using PLS Structural Equation Modelling (PLS-SEM) to analyze data. The sample of this research was consumer goods manufacturing in Indonesia and using primary data with questionnaire as data collection method. After analysis using PLS-SEM, researcher was found that supply chain management practices affect operational performance; and supply chain quality integration has mediating effect on the effect of supply chain management practices on operational performance of company.
\end{abstract}

Keywords: supply chain management practices, supply chain quality integration, supply chain performance, just-in-time capability, postponement

\section{Intisari}

Di perusahaan manufaktur, kualitas produk dapat menjadi kompetitif advantage untuk bersaing di pasar. Untuk mendapatkan kualitas aktifitas dan produk yang baik, perusahaan perlu memiliki sistem atau strategi untuk mengatur aktifitas rantai pasokan meningkatkan efektifitas dan efisiensi proses produksi dan meningkatkan kualitas persebaran informasi, waktu produksi, dan produk, sehingga perusahaan dapat meningkatkan performa mereka. Penelitian ini dilakukan guna mengetahui pengaruh mediasi dari kualitas integrasi rantai pasokan terhadap pengaruh praktik manajemen rantai pasokan untuk mencapai performa rantai pasokan yang lebih baik. Peneliti menggunakan PLS Structural Equation Modelling (PLS-SEM) dalam menganalisis primary data yang diperoleh melalui questionnaire terhadap perusahaan manufaktur barang konsumsi di Indonesia sebagai sampel penelitian. Setelah melakukan analisis data, peneliti menemukan bahwa praktik manajemen rantai pasokan dapat mempengaruhi performa operasional rantai pasokan dalam perusahaan; dan kualitas integrasi rantai pasokan dapat memediasi pengaruh praktik manajemen rantai pasokan terhadap performa operasional rantai pasokan.

Kata Kunci: praktik manajement rantai pasokan, kualitas integrasi rantai pasokan, performa rantai pasokan, kemampuan just-in-time, postponement 


\section{INTRODUCTION}

Supply Chain Management is important for the company. Supply chain management was defined as a set of strategy that was taken by the company to improve the effectiveness of supply chain (Li et al., 2005). The main objective of the supply chain management practice was to reduce the cycle and inventory time and increase product quality and productivity at the same time. In the long term period, supply chain management hopefully can improve the profit, market share, also customer satisfaction of company (Wisner, 2003). Supply chain management also has the ability to promote company integration in order to increase company collaboration (Ajmera \& Cook, 2009; Sundram et al., 2016).

In some manufacturing companies, they use just-in-time management practices on the production process. The just-in-time concept could improve quality control; reduce the lead time; improving the performance of the vendor; and waste elimination (Vokurka \& Lummus, 2000). In some conditions, manufacturing also decides to use the postponement management practice, or they delay the production for a period of time. They decide to do this activity to give the value added to their products and improve customer satisfaction (Sundram et al., 2016). For companies, it is important to manage their supply chain because applying an effective supply chain management could boost their customer satisfaction, reduce the operating cost and improve the quality of products, efficiency of production process, competitive advantages, and their financial position (Al-Shboul et al., 2017). But an effective supply chain management would improve the performance depends on how the management commitment and willingness to train their employee and improve the information quality among supply chain member, external or internal members.

With a good cooperative integration among supply chain members, the company can improve the performance by helping the company to solve the quality problem, reduce quality defects, and improve process and efficiency of production (Yu \& Huo, 2018). But, to be more competitive in the market, the company does not only need to have and manage good integration in supply chain activity, but they also need to have good supply chain quality integration. With managing good supply chain quality integration, the company can improve the efficiency and effectiveness of flow of production and quality sharing to improve the quality and value of the product, quality of production time, and low-cost product (Flynn et al., 2010; Huo et al., 2016).

Some company realized the importance of supply chain management for their supply chain activity, but usually they does not know what supply chain management practices they should implement (Sundram et al., 2016; Li et al., 2005); and although quality becoming the important things in a company that would gave them competitive advantage to compete in the market, company does not realize the importance of implementing supply chain quality integration in improving the quality of their supply chain activity and products (Huo et al., 2016; Yu and Huo, 2018). This could happen due to lack understanding of what constitutes a comprehensive set of supply chain management practices and what is supply chain quality integration and why it is important for the company.

Although previous researchers were given a clear understanding of how supply chain management affects the supply chain performance, or how supply chain management affects the supply chain integration, there are limited sources about supply chain quality integration and its role in mediating the effects of supply chain management practice to achieve better performance both operational and financial. Previous research has only examined the indirect effect of supply chain integration on supply chain practices and performances (Sundram et al., 2016); and the effects of supply chain quality integration on operational performance (Huo et al., 2016; Yu and Huo, 2018)). Consider the explanation above, the researcher 
interested to do the research with the title "The effect of Supply Chain Quality Integration on Supply Chain Management Practices to achieve Supply Chain Performance".

Researcher in this study will discuss two questions related to supply chain management. First is about the effect of supply chain management practices on supply chain performance. Second, the effect of supply chain quality integration in supply chain management practice to achieve supply chain performance.

In this study, the researcher will focus on two types of supply chain management which includes just-in-time capability and postponement. Just-in-time capability relates to the management practices to purchasing the materials based on the materials needed for production, producing the product at the time they receive the order from customers, and delivering the product to customers (Vokurka \& Lummus, 2000). While, postponement refers to the management practices when they need to delay or postpone the production process in order to improve the quality of product and meet customer satisfaction (Sundram et al., 2016). In manufacturing company, especially in consumer goods manufacturing company, just-in-time capability and postponement is the supply chain management practices that commonly used; but their supply chain management practices are not effectively improve the performance of the company because they does not know how to make the just-in-time capability and postponement to be effective for their condition in the company.

The researcher will analyze the impact of just-in-time capability and postponement management practice on the supply chain performance of the company either operationally (such as supplier-oriented performance and customer oriented performance), or financially (financial performance). The researcher also will analyze the effect of supply chain quality integration on supply chain management practices in improving the supply chain performance of the company.

To reduce the heterogeneity data, the researcher will do the research on consumer goods manufacturing company that was listed on the Indonesia Stock Exchange (IDX). The selection of consumer goods manufacturing industry was based on the company's production and sales activity.

\section{LITERATURE REVIEW}

\section{Supply Chain Management Practice}

Supply chain management practice refers to the practice or actions that were taken by the company in order to make effective and efficient management in supply chain activity (Gorane \& Kant, 2016). A good supply chain management should in line with our business strategy and management; in line with our customer needs; in line with our position and influence to supplier and customer; it also should be adaptive with the market condition and market change (Cohen \& Roussel, 2005). Supply chain management practice in a company has several objectives: (Wisner, 2003)

a. Short term objectives include Quality and productivity improvement while reducing inventory and cycle time;

b. Long term objectives include: Increase the customer satisfaction, increase the market share, also increase in profit of all networks in the supply chain.

In manufacturing company, supply chain management practice is important in order to: (Council of Supply Chain Management Professionals (CSCMP), n.d)

a. Boost customer service by delivering the correct product variance and quantity; locate the product in the right location, deliver product at the right time, and giving a right after sale support; 
b. Reduce operating costs by decreasing the cost of purchasing, decreasing the cost of production, and decreasing the cost of the total supply chain;

c. Improve the financial position by increasing the profit leverage, decrease the fixed asset, and increase the cash flow.

To make a good supply chain management and achieve the objectives of supply chain management practices, the company was adopted several kinds of supply chain management practices such as just-in-time capability and/or postponement. Just-in-time (JIT) capability refers to the system to synchronized the producing time so the company can produce appropriate items inappropriate amount of product inappropriate time (Gorane \& Kant, 2016). Several elements that just-in-time (JIT) management should have such as (Vokurka \& Lummus, 2000) including: quality control improvement; lead time reduction; improvement of vendor performance; improvement of total preventative maintenance; and elimination of waste.

Postponement management refers to the postpone or delay the producing process of a product to later point of time in order to improve the product, give the added value, and increase the customer satisfaction (Sundram et al., 2016). In a company, adopting postponement management will be appropriating in several conditions: innovative product, high monetary density product, high specialization, and wide range product, long delivery time product market, low frequency of delivery product, and high demand uncertainty (Li et al., 2005). Sometimes, the company needs to postpone their production because they want to improve their quality of the product or reducing the production cost cause of the high monetary density or low frequency of product that was ordered by customer.

\section{Supply Chain Quality Integration}

Supply chain quality integration is the combination of supply chain integration and quality management. Supply chain integration refers to the degree to which company collaborates and integrates the internal organization (divisions and staffs in the company) and external organization (supplier and customer) in order to make more effective and efficient flow of product and information sharing to improve the product value, time of production, with a low cost of production (Flynn et al, 2010). While, quality management focused on quality of products and services delivered to the customer (Huo et al., 2016). Based on description above, supply chain quality integration can be defined as the degree to which company collaborates and synchronize the internal organization with external organization parties in order to improve the efficiency and effectiveness of flow of production and quality of information sharing to improve the quality and value of product, quality of time production, and low cost product. There are two kinds of supply chain quality integration, which are internal and external quality integration.

Internal quality integration refers to the degree to which the company set the strategy, practice, and procedures for the internal parties in order to collaborate and synchronized the production process and quality of information sharing to fulfill the quality of customer requirements (Huo et al., 2016). While the external quality integration set the strategies for the external parties of the organization. External quality integration refers to the degree, to which organization integrates with the external parties to set the strategic, procedure, and practice to collaborate and synchronized the production process and quality of information sharing to improve the quality of customer requirements (Yu \& Huo, 2018). External quality integration could be separated into two types: supplier quality integration which refers to the degree of integration among company with their supplier; and customer quality integration which refers to the quality integration among company with their customers. 


\section{Supply Chain Performance}

Supply chain performance was referred to the systematic process to measure the effective and efficient supply chain activity in their company (Sundram et al., 2016). Supply chain performance could measure company's supply chain activity and management whether it has already achieved or not. There are two kinds of performance: operational performance and financial performance

Operational performance refers to the performance of the production process and quality in the manufacturing and distribution process to deliver the product in a timely and effective manner (Huo et al., 2014), which has two types of classifications: supplier-oriented performance and customer oriented performance. Supplier oriented performance relates to the manufacture perception about how their key supplier serves the manufacture with the quality, flexibility, and delivery of products. While, customer oriented performance relates to how the company will serve their customer with the quality, flexibility, and delivery of the product.

Financial performance will focus on evaluating financial aspects on performance such as sales growth, profitability and market share growth of the company.

\section{Hypothesis Development}

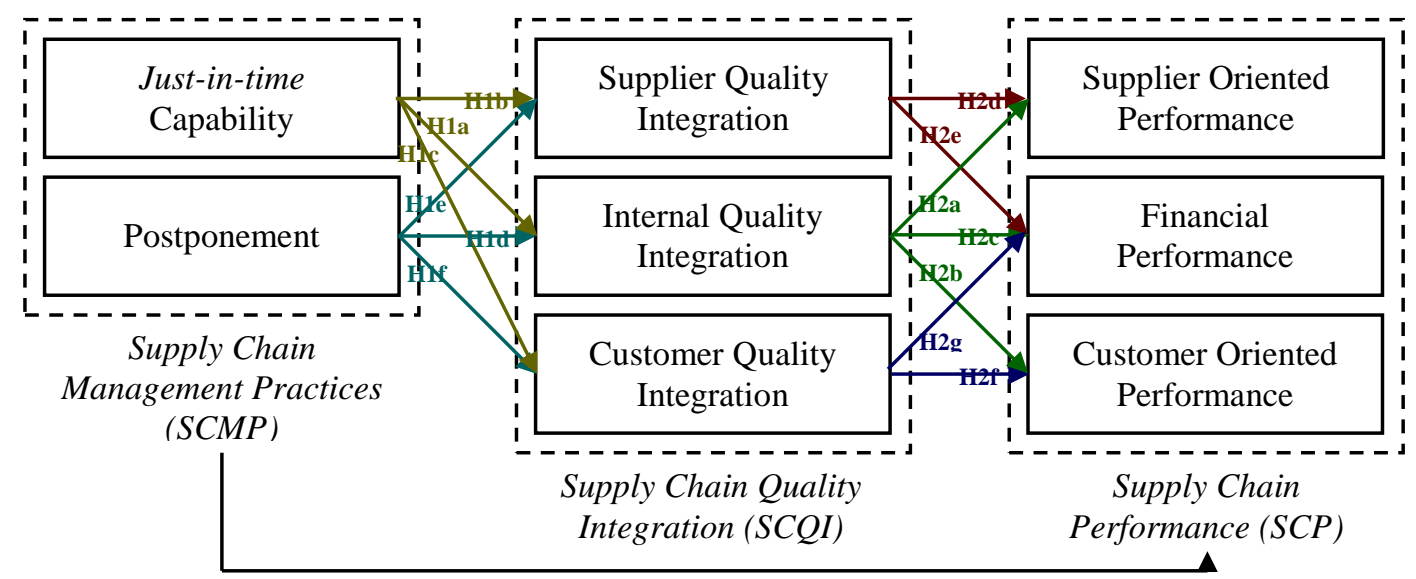

Figure 2.1 Research Model

(Adopted from Sundram et al. (2016), Huo et al. (2016) and Yu and Huo (2018))

\section{The Effect of Supply Chain Management Practice on Supply Chain Quality Integration}

Just-in-time (JIT) capability refers to how a company produces the appropriate items, with an appropriate amount, in an appropriate time (Gorane \& Kant, 2016). We can well manage this management system only when we can well manage the internal quality integration and external quality integration in the company. When we use just-in-time in the supply chain, we need to have good communication and information sharing with internal or external parties. If our integrations are not good enough, then our production process will face some problem cause of miscommunication or late information sharing. As the result, our production will be delayed or postponed. So, to make them just-in-time (JIT) management success, we also need to improve the supply chain quality integration. Thus, we proposed following hypothesis

Hla: The level of just-in-time capability has positive effect on the level of internal quality integration 
H1b: The level of just-in-time capability has positive effect on the level of supplier quality integration

H1c: The level of just-in-time capability has positive effect on the level of customer quality integration

Postponement management system refers to the system which we delayed or postponed the production in order to improve the quality of the product, give the value added, and give more innovation. In applying this management system, we need to improve our quality integration. The success postponement management depends on how management could be integrated internally and externally. For example, when the company needs to postpone product A for a couple month, so they do not need to order more raw materials and they also need to tell the reasons to the customer so they can reduce the cost of production and their customer will not be unsatisfied. Thus we proposed the following hypothesis:

H1d: The level of postponement has positive effect on the level of internal quality integration Hle: The level of postponement has positive effect on the level of supplier quality integration HIf: The level of postponement has positive effect on the level of customer quality integration (Hlf)

\section{The Impact of Supply Chain Quality Integration on Supply Chain Performance}

Internal quality integration relates to the integration among the internal parties of the company. When their internal integration such as quality of information sharing and communication were improved, they also could improve their performance. When their quality of information sharing and information improved - such as real-time information sharing, accurate information, etc - their production process will be improved so the delivery time and quality of the product will also improve. Their financial performance will also be improved since they could reduce the cost of production from unnecessary raw materials purchased. Thus researcher was proposed following hypothesis

H2a: The level of internal quality integration has positive effect on the level of supplier oriented performance

$H 2 b$ : The level of internal quality integration has positive effect on the level of customer oriented performance

H2c: The level of internal quality integration has positive effect on the level of financial performance

Supplier quality integration relates to the performance of the company. When the company can improve their integration with the supplier, they will have a close relationship with their supplier; as a result, our supplier will serve us better in quality, delivery, and flexibility of the product. So we could get the product we need on time and it also could reduce the cost of production. Thus researcher was proposed following hypothesis

H2d: The level of supplier quality integration has positive effect on the level of supplier oriented performance

H2e: The level of supplier quality integration has positive effect on the level of financial performance

Customer integration relates to the organization performance. If our customer integration improved, then we will serve our customer better. When it improved, we could better understanding about what the need and what they want, so we could serve better quality, 
delivery, and flexibility of the product to fulfill customer needs. Thus researcher was proposed following hypothesis

H2f: The level of customer quality integration has positive effect on the level of customer oriented performance

H2g: The level of customer quality integration has positive effect on the level of financial performance $(\mathrm{H} 2 \mathrm{~g})$

\section{The Effect of Supply Chain Management Practice on Supply Chain Performance}

Supply chain management practice was referring to set of tools that were taken by the management of the company to improve the efficiency and effectiveness of supply chain activity in the company (Gorane \& Kant, 2016). Good supply chain management practice could reflect the performance of the company. The objective of supply chain management was to improve the performance of the company both operational and financial (Al-Shboul et al., 2017; Wisner, 2003). Therefore, the researcher formulated the following hypothesis:

H3a: The level of just-in-time capability has positive effect on the level of supplier oriented performance

H3b: The level of just-in-time capability has positive effect on the level of customer oriented performance

H3c: The level of just-in-time capability has positive effect on the level of financial performance

H3d: The level of postponement has positive effect on the level of supplier oriented performance

H3e: The level of postponement has positive effect on the level of customer oriented performance

H3f: The level of postponement has positive effect on the level of financial performance

\section{Mediating Effect of Supply Chain Quality Integration}

The effect of supply chain management practice on the performance will not be direct and universal. This relationship will depend on how the supply chain quality integration that was set and applied in the company (Sundram et al, 2016). When their supply chain management practice was good but their supply chain quality integration not good, it may affect the performance (it may be good or bad). It depends on how integrative capabilities of the organization across the supply chain. Based on this, we proposed:

H4: Supply chain quality integration will mediate the supply chain management practice in achieving supply chain performance

\section{RESEARCH METHOD}

To test the hypothesis, researcher collected the data from consumer goods manufacturing industry listed on Indonesia Stock Exchange (IDX), especially in consumer goods industry. The reasons for only focus on manufacturing industry; first, to minimize the heterogeneous data. Second, the manufacturing industry is one type of business which has a complete supply chain activity. It does not mean that other industry does not have a supply chain activity, but supply chain activity in the manufacturing industry is more complete and clear to analyze rather than another type of industry. Third, compared to another two sub-sector in the manufacturing sector, consumer goods industry is one of the most active sub-sector in trading their share in Indonesia Stock Exchange (IDX). The survey questionnaire was separated into 
a total of 51 consumer goods manufacturer that was randomly selected from the Indonesian Stock Exchange (IDX). The survey was conducted over a span of 4 months. As a result, a total of 22 were collected and the final response rate was 43.14 percent.

In collecting data, researcher was using primary data. Researcher collecting the primary data by doing the survey questionnaire which divided into four main sections of the survey questionnaire: respondent profile, supply chain management practice, supply chain quality integration, and supply chain performance.

\section{RESULT ANALYSIS, DISCUSSION, AND IMPLICATION}

\section{Sample Profile}

After conducting the research for four months (start from September 2018 until January 2019) and distributing the research questionnaire to 51 consumer goods manufacturing in Indonesia, researcher was collected responses from 22 firms with final response rate 43.14 percent. The respondent firms were from several sectors in consumer goods manufacturing industry that was listed on Indonesian Stock Exchange (IDX), which are: food and beverage (50.00 percent), pharmaceutical (18.18 percent), cosmetic and household (13.64 percent), tobacco manufactures (9.09 percent), and house-ware (9.09 percent).

Table 4.1 Respondents Firm Profile

\begin{tabular}{|c|c|c|c|c|}
\hline \multicolumn{2}{|c|}{$\begin{array}{l}\text { Sector in Consumer Goods } \\
\text { Manufacture }\end{array}$} & \multicolumn{3}{|c|}{ Number of Employees } \\
\hline Food and Beverages & $50.00 \%$ & $<5,000$ employees & & $45.45 \%$ \\
\hline Tobacco Manufacturer & $9.09 \%$ & $\begin{array}{lll}5,000 & - & 1 \\
\text { employees }\end{array}$ & 10,000 & $27.27 \%$ \\
\hline Pharmaceuticals & $18.18 \%$ & $\begin{array}{l}10,000 \\
\text { employees }\end{array}$ & 15,000 & $9.09 \%$ \\
\hline $\begin{array}{l}\text { Cosmetics } \\
\text { Household }\end{array}$ & $13.64 \%$ & $\begin{array}{l}15,000 \\
\text { employees }\end{array}$ & 20,000 & $4.55 \%$ \\
\hline House-ware & $9.09 \%$ & $\begin{array}{l}20,000 \\
\text { employees }\end{array}$ & 25,000 & $0.00 \%$ \\
\hline Others & $0.00 \%$ & $>25,000$ employees & & $13.64 \%$ \\
\hline \multicolumn{2}{|l|}{ Annual Sales } & \multicolumn{3}{|c|}{ Operating Experience } \\
\hline$<1$ billions rupiah & $18.18 \%$ & $<20$ years & & $9.09 \%$ \\
\hline $1-20$ billions rupiah & $50.00 \%$ & $20-40$ years & & $40.91 \%$ \\
\hline 20 - 40 billions rupiah & $18.18 \%$ & $40-60$ years & & $36.36 \%$ \\
\hline 40 - 60 billions rupiah & $4.55 \%$ & $60-80$ years & & $0.00 \%$ \\
\hline 60 - 80 billions rupiah & $4.55 \%$ & $80-100$ years & & $9.09 \%$ \\
\hline$>80$ billions rupiah & $4.55 \%$ & $>100$ years & & $4.55 \%$ \\
\hline
\end{tabular}

\section{Reliability and Validity}

To verify the reliability and validity of the model, researcher used internal consistency reliability, convergent validity, and discriminant validity as the criteria of evaluation measurement model. Composite reliability $(\rho c)$ and Cronbach's alpha $(\alpha)$ were used to analyze the internal consistency reliability. In testing convergent validity, researcher used loadings factor and average variance extracted (AVE). Fornell-Larcker criterion to test the discriminant validity. 
Internal consistency reliability was achieved when the composite reliability $(\rho c)$ and Cronbach's alpha $(\alpha)$ were fulfilled the criteria. Based on Ghozali (2008), to fulfill the criteria of reliability data, Cronbach's alpha $(\alpha)$ should be greater than 0.70 ; and composite reliability will be fulfilled at point 0.70 or greater, but 0.60 and 0.50 still can be supported. As shown in Table 4.2, the value of Cronbach's alpha $(\alpha)$ and the composite reliability $(\rho \mathrm{c})$ was greater than 0.70 which shows that the model fulfill the criteria of internal consistency reliability.

Convergent validity was tested using loadings factor and average variance extracted (AVE). In fulfilling the criteria of convergent validity, loading factors should be at $/ \mathrm{more}$ than 0.50; and average variance extracted (AVE) should be more than 0.50. Table 4.2 shows that loadings factor and average variance extracted (AVE) was exceeded 0.50; and the research model fulfilled the criteria of convergent validity.

Table 4.2 Internal Consistency Reliability and Convergent Validity

\begin{tabular}{|c|c|c|}
\hline & & Loading \\
\hline \multicolumn{3}{|l|}{ Supply chain Management Practices } \\
\hline Just-in-time Capability & JIT01 & 0.759 \\
\hline \multirow[t]{7}{*}{$(\rho c=0.914 ; \alpha=0.900 ; \mathrm{AVE}=0.582)$} & JIT02 & 0.743 \\
\hline & JIT03 & 0.832 \\
\hline & JIT04 & 0.801 \\
\hline & JIT05 & 0.885 \\
\hline & JIT06 & 0.841 \\
\hline & JIT07 & 0.756 \\
\hline & JIT08 & 0.511 \\
\hline \multirow{4}{*}{$\begin{array}{l}\text { Postponement } \\
\qquad(\rho \mathrm{c}=0.847 ; \alpha=0.766 ; \mathrm{AVE}=0.582)\end{array}$} & POS01 & 0.769 \\
\hline & POS02 & 0.729 \\
\hline & POS03 & 0.792 \\
\hline & POS04 & 0.742 \\
\hline \multicolumn{3}{|l|}{ Supply Chain Quality Integration } \\
\hline \multirow{9}{*}{$\begin{array}{l}\text { Internal Quality Integration } \\
\qquad(\rho c=0.943 ; \alpha=0.934 ; \text { AVE }=0.626)\end{array}$} & IQI01 & 0.782 \\
\hline & IQI02 & 0.835 \\
\hline & IQI03 & 0.720 \\
\hline & IQI04 & 0.848 \\
\hline & IQI05 & 0.830 \\
\hline & IQI06 & 0.828 \\
\hline & IQI07 & 0.777 \\
\hline & IQI08 & 0.688 \\
\hline & IQI09 & 0.718 \\
\hline \multirow{9}{*}{$\begin{array}{l}\text { Supplier Quality Integration } \\
\qquad(\rho c=0.901 ; \alpha=0.875 ; \mathrm{AVE}=0.509)\end{array}$} & SQI01 & 0.628 \\
\hline & SQI02 & 0.731 \\
\hline & SQI03 & 0.712 \\
\hline & SQI04 & 0.735 \\
\hline & SQI05 & 0.608 \\
\hline & SQI06 & 0.851 \\
\hline & SQI07 & 0.822 \\
\hline & SQI08 & 0.703 \\
\hline & SQI09 & 0.541 \\
\hline Customer Quality Integration & CQI01 & 0.314 \\
\hline
\end{tabular}




\begin{tabular}{ccc}
\hline$(\rho \mathrm{c}=0.897 ; \alpha=0.869 ; \mathrm{AVE}=0.509)$ & CQI02 & 0.346 \\
& CQI03 & 0.805 \\
& CQI04 & 0.393 \\
& CQI05 & 0.774 \\
& CQI06 & 0.783 \\
Supply Chain Performance & & \\
Supplier Oriented Performance & SOP01 & 0.682 \\
$(\rho \mathrm{c}=0.911 ; \alpha=0.920 ;$ AVE $=0.634)$ & SOP02 & 0.840 \\
& SOP03 & 0.914 \\
& SOP04 & 0.703 \\
Customer Oriented Performance & SOP05 & 0.818 \\
$(\rho c=0.920 ; \alpha=0.894 ;$ AVE $=0.661)$ & SOP06 & 0.819 \\
& COP01 & 0.656 \\
COP02 & 0.744 \\
Financial Performance & COP03 & 0.953 \\
$(\rho c=0.960 ; \alpha=0.955 ;$ AVE $=0.729)$ & COP04 & 0.759 \\
& COP05 & 0.932 \\
& COP06 & 0.800 \\
& FP01 & 0.793 \\
& FP02 & 0.728 \\
& FP03 & 0.842 \\
& FP04 & 0.771 \\
& FP05 & 0.912 \\
& FP06 & 0.921 \\
& FP07 & 0.880 \\
& FP08 & 0.893 \\
\hline
\end{tabular}

Note: Composite reliability $(\rho c) \geq 0.70$; Cronbach's alpha $(\alpha) \geq 0.70$; Average variance extracted $(\mathrm{AVE}) \geq 0.50$; Loading factor $\geq 0.50$

To test the discriminant validity of the data, researcher used Fornell-Lercker criterion. In Fornell-Lercker criterion, the square root of average variance extracted (AVE) should be higher than constructs correlations with other constructs in the model. Table 4.3 shows that the square root average variance extracted (AVE) in the diagonal elements were higher than other constructs correlations. Other criteria of discriminant validity is the cross loadings of intended factors should be greater than loadings of other factors. Appendix $\mathrm{C}$ shows that cross loadings factor of intended factors was higher than loadings factor of other constructs. Based on Fornell-Larcker criteria and Cross Loadings factor, these research model was fulfilled the criteria of discriminant validity.

Table 4.3 Discriminant Validity

\begin{tabular}{lcccccccc}
\hline & JIT & POS & IQI & SQI & CQI & SOP & COP & FP \\
\hline Just-in-time Capability & $\mathbf{0 . 7 6 3}$ & & & & & & & \\
Posponement & 0.280 & $\mathbf{0 . 7 6 3}$ & & & & & & \\
Internal Quality Intg & 0.394 & 0.156 & $\mathbf{0 . 7 9 1}$ & & & & & \\
Supplier Quality Intg & 0.500 & 0.238 & 0.811 & $\mathbf{0 . 7 1 4}$ & & & & \\
Customer Quality Intg & 0.453 & 0.514 & 0.552 & 0.753 & $\mathbf{0 . 7 1 4}$ & & & \\
Supplier Oriented Perf & 0.593 & 0.501 & 0.445 & 0.631 & 0.511 & $\mathbf{0 . 7 9 7}$ & & \\
Customer Oriented Perf & 0.446 & 0.498 & 0.656 & 0.687 & 0.709 & 0.674 & $\mathbf{0 . 8 1 3}$ & \\
\hline
\end{tabular}

DOI: http://dx.doi.org/10.33021/jaaf.v3i2.809 


\begin{tabular}{lllllllll}
\hline Financial Performance & 0.180 & 0.146 & 0.600 & 0.444 & 0.114 & 0.341 & 0.449 & $\mathbf{0 . 8 5 4}$ \\
Mean & 0.893 & 0.754 & 0.936 & 0.875 & 0.860 & 0.870 & 0.885 & 0.956 \\
Standard Deviation & 0.042 & 0.079 & 0.022 & 0.037 & 0.038 & 0.060 & 0.028 & 0.013 \\
\hline
\end{tabular}

Note: Diagonal items are square root of AVE

\section{Structural Model}

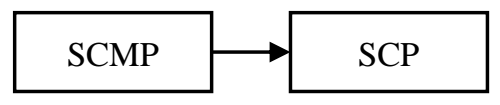

Panel A Direct Effect

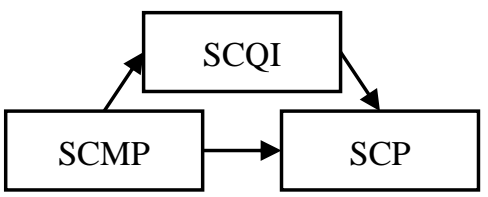

Panel B Indirect Effect

Figure 4.1 Direct and Indirect Effect of Supply Chain Management Practice on Performance

In assessing the multicollinearity, researcher used variance inflation factors (VIF) that should be greater than 10. As showed in Appendix B, research model in this research, variance inflation factors (VIF) was below 10, thus fulfilled collinearity criteria.

In structural modelling, researcher used path coefficient $(\beta), p$-value, and T-value to test the effect and significant level between two variables. Path coefficient defines as value of effect/relation of latent variable. To determine the effect of one variable to other variable, researcher was used P-value with significant at $p \leq 0.05$. T-value will analyse the variable have significant effect to another variable or no significant effect. When T-value were greater than T-tables (in this research $=1.96(\alpha=0.05$; two tailed)).

Table 4.4 Result of Hypothesis Test

\begin{tabular}{lccll}
\hline & $\beta$ & T-Value & \multicolumn{2}{c}{ Hypothesis } \\
JIT Capability $\rightarrow$ IQI & $0.380^{* *}$ & 1.967 & H1a & Supported \\
JIT Capability $\rightarrow$ SQI & $0.470^{*}$ & 2.580 & H1b & Supported \\
JIT Capability $\rightarrow$ CQI & $0.335^{* * *}$ & 1.954 & H1c & Supported \\
POS $\rightarrow$ IQI & 0.068 & 0.238 & H1d & Not Supported \\
POS $\rightarrow$ SQI & 0.171 & 0.692 & H1e & Not Supported \\
POS $\rightarrow$ CQI & $0.531^{* * *}$ & 1.952 & H1f & Supported \\
IQI $\rightarrow$ SOP & -0.136 & 0.441 & H2a & Not Supported \\
IQI $\rightarrow$ COP & $0.491^{* *}$ & 2.097 & H2b & Supported \\
IQI $\rightarrow$ FP & $0.608^{* * *}$ & 1.960 & H2c & Supported \\
SQI $\rightarrow$ SOP & $0.773 *$ & 2.889 & H2d & Supported \\
SQI $\rightarrow$ FP & 0.435 & 1.004 & H2e & Not Supported \\
CQI $\rightarrow$ COP & $0.541^{* *}$ & 2.531 & H2f & Supported \\
CQI $\rightarrow$ FP & -0.482 & 1.470 & H2g & Not Supported \\
JIT $\rightarrow$ SOP & $0.520^{*}$ & 2.612 & H3a & Supported \\
JIT $\rightarrow$ COP & $0.316^{* * *}$ & 1.679 & H3b & Supported \\
JIT $\rightarrow$ FP & 0.214 & 0.961 & H3c & Not Supported \\
POS $\rightarrow$ SOP & 0.322 & 1.501 & H3d & Not Supported \\
POS $\rightarrow$ COP & $0.429^{* *}$ & 2.196 & H3e & Supported \\
POS $\rightarrow$ FP & 0.141 & 0.556 & H3f & Not Supported \\
\hline
\end{tabular}

Note: Significant at $* \mathrm{p}<0.01 ; * * \mathrm{p}<0.05 ;$ and $* * * \mathrm{p}<0.1$

Significant when T-Values was greater than T-Table (confidence level 0.05; two tailed (1.96)) 
Based on the criteria and result of hypothesis testing, the following result was concluded to answer the research questions. In this research, it was found that just-in-time capability in supply chain management practices have significant and positive effect on internal quality integration $(\beta=0.380 ; \mathrm{p} \leq 0.05 ; \mathrm{t} \geq 1.96)$ and supplier quality integration $(\beta=0.470 ; \mathrm{p} \leq$ $0.05 ; \mathrm{t} \geq 1.96)$. Postponement in supply chain management practices has no effect on internal quality integration and supplier quality integration. Customer quality integration was positively affected by just-in-time capability $(\beta=0.335 ; \mathrm{p} \leq 0.1 ; \mathrm{t} \leq 1.96)$ and postponement $(\beta=0.531 ; \mathrm{p} \leq 0.1 ; \mathrm{t} \leq 1.96)$ but not significant. Thus, results of hypothesis $\mathrm{H} 1 \mathrm{a}, \mathrm{H} 1 \mathrm{~b}, \mathrm{H} 1 \mathrm{c}$, and H1f are supported; while hypothesis H1d and H1e are not supported.

Internal quality integration in supply chain quality integrations was found to have positive significant effect on customer oriented performance $(\beta=0.491 ; \mathrm{p} \leq 0.05 ; \mathrm{t} \geq 1.96)$; not significant positive effect to financial performance $(\beta=0.608 ; \mathrm{p} \leq 0.1 ; \mathrm{t} \leq 1.96)$; and internal quality integration has no effect on supplier oriented performance. External quality integrations were found to have positive and significant effect on operational performance (supplier $(\beta=0.773 ; \mathrm{p} \leq 0.05 ; \mathrm{t} \geq 1.96)$ and customer $(\beta=0.541 ; \mathrm{p} \leq 0.05 ; \mathrm{t} \geq 1.96)$ oriented performance), and it has no effect on financial performance. It results supported for hypothesis $\mathrm{H} 2 \mathrm{~b}, \mathrm{H} 2 \mathrm{c}, \mathrm{H} 2 \mathrm{~d}$, and $\mathrm{H} 2 \mathrm{f}$; and not supported hypothesis $\mathrm{H} 2 \mathrm{a}, \mathrm{H} 2 \mathrm{e}$, and $\mathrm{H} 2 \mathrm{~g}$.

In line with previous research, just-in-time capability was found to have positive and significant direct effect on supplier oriented performance $(\beta=0.520 ; \mathrm{p} \leq 0.05 ; \mathrm{t} \geq 1.96)$. Justin-time also found to have not significant positive direct effect on customer oriented performance $(\beta=0.316 ; \mathrm{p} \leq 0.1 ; \mathrm{t} \leq 1.96)$. Postponement found to have positive and significant direct effect on customer oriented performance $(\beta=0.429 ; \mathrm{p} \leq 0.05 ; \mathrm{t} \geq 1.96)$, and found to have no effect on supplier oriented performance. Financial performance was not affected by supply chain management practice either just-in-time capability or postponement. This result was supported hypothesis $\mathrm{H} 3 \mathrm{a}, \mathrm{H} 3 \mathrm{~b}$, and $\mathrm{H} 3 \mathrm{e}$; and rejected hypothesis $\mathrm{H} 3 \mathrm{c}, \mathrm{H} 3 \mathrm{~d}$, and $\mathrm{H} 3 \mathrm{f}$.

\section{Mediating Effect Testing}

In testing the mediating effects of supply chain quality integration on supply chain management practices to achieve performance, researcher adopted mediation analysis procedure from Hair et al. (2017). First, researcher tested the significance level of indirect effect via mediating variable. If there is no significance level of indirect effect, it means that there is only direct effect (if there is significant level of direct effect) or no effect (if there is no significance level of direct effect). If there is significance level of indirect effect, researcher continued to next step of mediation analysis procedure.

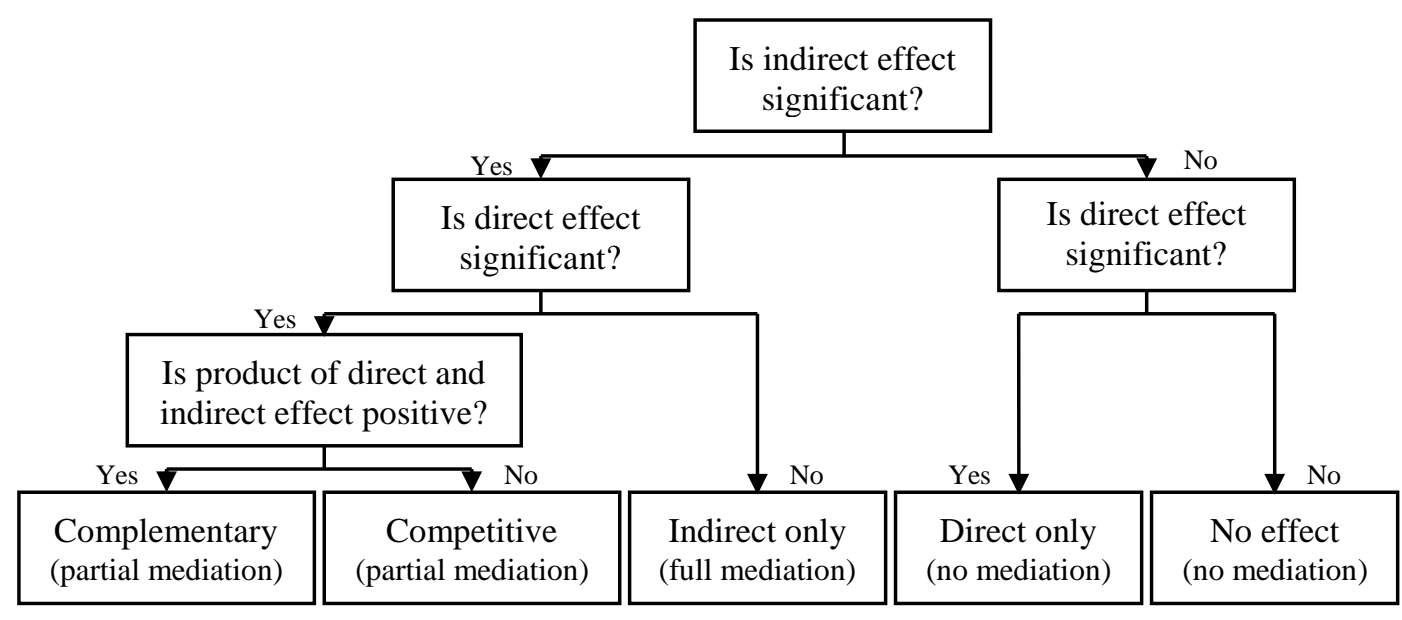

Figure 4.2 Mediating Analysis Procedure 
Second, researcher tested the significance level of direct effect. If there is no significant level of direct effect, it means the mediating variable was fully mediated the effect of independent and dependent variable. If there is significant level of direct effect, researcher continued to next step of mediation procedure.

Third, researcher tested the positive and negative product of direct and indirect effect. Positive product of direct and indirect effect means that the indirect path has same direction as direct path. While, negative product of direct and indirect effect means that indirect path has opposite direction as direct path. If the products of direct and indirect effects are positive, it means that the mediating variable has complementary partial mediating effect on dependent and independent variable. If the products of direct and indirect effects are negative, it means that the mediating variable has competitive partial mediating effect on dependent and independent variable. Figure 4.2 was clearly shows us the procedure of mediating analysis from Hair et al. (2017).

Table 4.5 Mediating Analysis

\begin{tabular}{lcccccc}
\hline & \multicolumn{2}{c}{ Indirect } & \multicolumn{2}{c}{ Direct } & \multirow{2}{*}{ Mediate } & \multirow{2}{*}{ Product } \\
& $\mathrm{B}$ & T-Value & $\mathrm{B}$ & T-Value & & \\
\hline $\mathrm{JIT} \rightarrow$ SOP & $0.295^{* *}$ & 2.349 & $0.520^{*}$ & 2.612 & Yes & Positive \\
$\mathrm{JIT} \rightarrow$ COP & $0.301^{* *}$ & 2.412 & $0.316^{* * *}$ & 1.679 & Yes & Positive \\
$\mathrm{JIT} \rightarrow$ FP & 0.222 & 1.267 & 0.214 & 0.961 & No & Positive \\
$\mathrm{POS} \rightarrow$ SOP & 0.074 & 0.449 & 0.322 & 1.501 & No & Positive \\
$\mathrm{POS} \rightarrow$ COP & 0.229 & 1.053 & $0.429 * *$ & 2.196 & No & Positive \\
POS $\rightarrow$ FP & -0.120 & 0.574 & 0.141 & 0.556 & No & Negative \\
\hline
\end{tabular}

Note: Significant at $* \mathrm{p}<0.01 ; * * \mathrm{p}<0.05 ;$ and $* * * \mathrm{p}<0.1$

Significant when T-Values was greater than T-Table (confidence level 0.05; two tailed (1.96))

Based on criteria of mediating analysis procedure by Hair et al. (2017), researcher found that supply chain quality integration as mediating variable was partially mediate the effect of just-in-time capability on operational performance ( $\operatorname{supplier}(\beta=0.295 ; \mathrm{p} \leq 0.05 ; \mathrm{t} \geq 1.96)$ and customer oriented performance $(\beta=0.301 ; \mathrm{p} \leq 0.05 ; \mathrm{t} \geq 1.96))$. Supply chain quality integration was not found to mediate the effect of just-in-time capability on financial performance; and also the effect of postponement on supply chain performance. Thus the result was supported by hypothesis $\mathrm{H} 4$.

\section{Discussion and Theory Implications}

After conducting research in consumer goods manufacturing industry listed in Indonesian Stock Exchange (IDX), researcher found several information regard "the effect of supply chain quality integration on supply chain management practice to achieve supply chain performance".

\section{The Effect of Supply Chain Management Practices on Supply Chain Quality Integration}

Supply chain quality integration refers to the degree to which company synchronized and collaborates internal and external organization functions in order to improve the effectiveness and efficiency flow of production and quality of information sharing in order to improve the quality and value of product, quality of time production, and low cost product (Flynn et al., 2010; Huo et al., 2016). Just-in-time (JIT) capability refers to how a firm produces the appropriate items, with an appropriate amount, in an appropriate time (Gorane \& Kant, 
2016). When firms applying just-in-time capability in their supply chain management practices and well managing their just-in-time capability, it will result the positive effects on their supply chain quality integration.

Researcher found that just-in-time capability has positive effect on internal quality integration, supplier quality integration, and customer quality integration. It reflects that by well managing their just-in-time capability in supply chain management practices, firms can improve their quality integration within internal functions and external functions of supply chain members. When the quality integration within internal functions improve, they can improve their efficiency and effectiveness of production process by improving the quality of information sharing (accuracy and real time information sharing), improving communication in problem solving, and coordination activities. When the quality integration with supplier improve, the company can manage the close relationship with supplier in order to help supplier improve their quality of product, communicate the design changes to meet our criteria of product quality. By applying just-in-time capability, company quality integration with customer will be improved by managing close relationship with customer in order to well understand customer demands, improve quality of products, and solve the problems with customer.

Postponement in supply chain management practice referred to the activities of delay or postpone the production process to later point of time in order to improve the products quality, give added value, and increase customer satisfaction (Sundram et al., 2016). By applying and well managing postponement in supply chain management, company quality integration with customer will be improved also. Postponement management practices allow company to delay or postpone their production process to later point of time, then company can give value added to their products, or customer can give input to the company about the quality of product development.

\section{The Effect of Supply Chain Quality Integration on Supply Chain Performance}

Supply chain quality integration was divided into two types which are: internal quality integration and external quality integration. By applying supply chain quality integration, company could improve their performance of supply chain activity. Result in this study found that supply chain quality integration has positive effect on performance of operational activities in company. By applying supply chain quality integration, company can quickly modify the products to meet criteria of customer quality of products needed. Company also can introduce their new product faster, improve the lead time production which resulted on time delivery product of customer, and improve customer satisfaction. Supplier of company also can improve their performance by reducing the lead time of production, introduced new product faster, and quickly modified the products. But, by applying supply chain quality integration, the financial performance of the company would not be affected, which means that the sales and profit with and without supply chain quality integration will not change.

\section{The Effect of Supply Chain Management Practices on Supply Chain Performance}

Operational performance (supplier oriented performance and customer oriented performance) were affected by just-in-time capability and postponement. With just-in-time capability in supply chain management practice, company can improve their operational performance. It is because when company applied just-in-time capability, they would produce their product in appropriate time with appropriate amount, and it resulted the efficient and effective of production process. If company can improve the efficiency and effectiveness of production process, company can reduce the lead time of production process and deliver the products on time. With postponement in supply chain management practice, company can quickly respond the changes of market demands, quickly modify their products, and quickly 
introduced the new products to the market. This result was confirmed previous research from Dong et al (2001) that high level just-in-time capability in company supply chain management practices would improve the performance of the company. Also, the high level postponement would improve the performance of the company (Sundram et al., 2016).

Financial performance of the company would not affect by supply chain management practice either just-in-time capability and postponement. It is because by applying just-in-time capability and postponement, financial performance of the company such as sales and profit will not changes.

\section{The Mediating Effect of Supply Chain Quality Integration on Supply Chain Management Practices to achieve Supply Chain Performance}

Supply chain quality integration found that it has partial mediating effect on supply chain management practice in achieving supply chain performance. Just-in-time capability would directly affect and improve the supply chain performance of company. The effect of just-in-time capability to supply chain performance would be affected by supply chain quality integration. By applying supply chain quality integration, their just-in-time capability in supply chain management practice would be more effective and efficient to achieve supply chain performance.

The effect of postponement in supply chain management practice to achieve supply chain performance would not be affected by supply chain quality integration. Postponement only has direct effect to supply chain performance. It means that the effect of postponement to supply chain performance with/without supply chain quality integration will not be changes.

\section{CONCLUSION, LIMITATIONS, AND SUGGESTIONS}

\section{Conclusion}

Result in this study found that supply chain management practices would positively affect supply chain quality integration and operational performance in supply chain performance of the company. By applying and well managing the supply chain management practices, company can improve their effectiveness and efficiency of production and quality of information sharing and improve the quality integration within internal functions of the company, and between company and external functions of company. Supply chain management practice would improve the performance of the company by reducing the lead time of production, quickly modify the product and introduced the new product to the market. Company also can analyze quickly and understand the changes in demand on the market.

Supply chain quality integration has positive effect on supply chain performance of the company. Supply chain quality integration would help company to set strategy and procedure to improve the effective and efficient production process and quality of information sharing. With good quality integration on supply chain management practice, company can understand the changes on the demand of market better, quickly introduced new product on the market, and quickly modify the product to meet customer criteria of product and achieve customer satisfaction.

This research also found that Supply chain quality integration has mediating effect on the effect of supply chain management practice to achieve operational performance in company. By applying supply chain quality integration, the supply chain management practices on the company would improve and the supply chain performance also would be improved.

\section{Limitations}

Several limitations related to the data analysis and data collection is that this study only focused on one sector of the manufacturing industry which has the most activities in 
production and selling in order to minimize the heterogeneity of the data resulted from this research. The result of this study might be different with the conditions of other sector in manufacturing industry or business. Second, the researcher only took the small amount of sample according to the data of consumer goods manufacturing industry that only was listed in Indonesia Stock Exchange (IDX). So, if researcher takes the bigger population such as all consumer goods manufacturing in Indonesia both listed or not listed in IDX it could reflect the different result also. Third, this research was held in a limited point of time (4 months). It might not see the changes or trends of how supply chain management practices would affect supply chain performance in different period of time. Last, researcher in this research was only focus on two types of supply chain management practice which are just-in-time capability and postponement.

\section{Suggestions}

Future research can be applied in a different sector of the company and held a long time period of research, so that the trends in supply chain activity can be analyzed. Future research also can find another combination of the supply chain management practice - besides just-intime capability and postponement such as agreed vision and goals and/or risk and reward sharing - that will influence the supply chain performance with supply chain quality integration. Besides, finding the new combination of supply chain quality integration or finding another measurement that would influence the supply chain management practice will have different result for supply chain performance.

\section{REFERENCES}

Ajmera, A. \& Cook, J. (2009). A multi-phase framework for supply chain integration. SAM Advanced Management Journal, 74(1), 37-49.

Al-Shboul, M. A. R., Barber, K. D., Garza-Reyes, J. A., Kumar, V., \& Abdi, M. R. (2017) The effect of supply chain management practices on supply chain and manufacturing firms' performance. Journal of Manufacturing Technology Management, 28 (5), 577609. https://doi.org/10.1108/JMTM-11-2016-0154

Cohen, S. \& Roussel J. (2005). Strategic supply chain management: The five disciplines for top performance. USA: McGraw-Hill. DOI: 10.1036/0071454497

Dong, Y., Carter, C. R., \& Dresner, M. E. (2001). JIT purchasing and performance: an exploratory analysis of buyer and supplier perspectives. Journal of Operations Management, 19 (4), 471-483. https://doi.org/10.1016/S0272-6963(00)00066-8

Flynn, B. B., Huo, B., \& Zhao, X. (2010). The impact of supply chain integration on performance: A contingency and configuration approach. Journal of Operations Management, 28 (1), 58-71. https://doi.org/10.1016/j.jom.2009.06.001

Ghozali, I. (2008). Structural Equation Modeling metode alternatif dengan Partial Least Square (2nd ed.). Indonesia: Badan Penerbit Universitas Diponegoro. ISBN: 9797042509

Gorane, S. J. \& Kant, R., (2016). Supply chain practices: An implementation status in Indian manufacturing organizations. Benchmarking: An International Journal, 23 (5), 10761110. https://doi.org/10.1108/BIJ-06-2014-0059

Hair, J. F. Jr., Hult, G. T. M., Ringle, C. M., \& Sarstedt, M. (2017). A primer on Partial Least Squares Structural Equation Modeling (PLS-SEM) (2nd ed.). Los Angeles: SAGE Publications, Inc. ISBN: 9781483377445

Huo, B., Zhao, X., \& Lai, F. (2014). Supply chain quality integration: antecedents and consequences. IEEE Transactions on Engineering Management, 61 (1), 38 - 51. DOI: 10.1109/TEM.2013.2278543

DOI: http://dx.doi.org/10.33021/jaaf.v3i2.809 
Huo, B., Ye, Y., Zhao, X., \& Zhu, K. (2016). Supply chain quality integration: A taxonomy perspective. International Journal of Production Economics, 207, 236-246. https://doi.org/10.1016/j.ijpe.2016.05.004

Huo, B. (2012). The impact of supply chain integration on company performance: An organizational capability perspective. Supply Chain Management: An International Journal, 17 (6), 596-610. http://dx.doi.org/10.1108/13598541211269210

Li, S., Rao, S. S., Ragu-Nathan, T. S., \& Ragu-Nathan, B. (2005). Development and validation of a measurement instrument for studying supply chain management practices. Journal of Operations Management, 23 (6), 618-641. https://doi.org/10.1016/j.jom.2005.01.002

Mentzer, J. T., DeWitt, W., Keebler, J. S., Min, S., Nix, N. W., Smith, C. D., \& Zacharia, Z. G. (2001). Defining supply chain management. Journal of Business Logistics, 22 (2), 1 25. DOI: 10.1002/j.2158-1592.2001.tb00001.x

Sundram, V. P. K., Chandran, V. G. R., \& Bhatti, M. A., (2016). Supply chain practices and performance: The indirect effects of supply chain integration. Benchmarking: An International Journal, 23 (6), 1445-1471. https://doi.org/10.1108/BIJ-03-2015-0023

The importance of supply chain management (n.d). In Council of Supply Chain Management Professionals (CSCMP). Retrieved February 1, 2019, from https://cscmp.org/CSCMP/Develop/Starting_Your_SCM_Career/Importance_of_SCM/ CSCMP/Develop/Starting_Your_Career/Importance_of_Supply_Chain_Management.a spx?hkey=cf46c59c-d454-4bd5-8b06-4bf7a285fc65

Vokurka, R. J. \& Lummus, R. R. (2000). The role of just-in-time in supply chain management. The International Journal of Logistics Management, 11 (1), 89-98. http://dx.doi.org/10.1108/09574090010806092

Vollmann, T. E., Cordon, C., \& Heikkila, J. (2000). Teaching supply chain management to business executives. Production and Operations Management, 9 (1), 81-90. https://doi.org/10.1111/j.1937-5956.2000.tb00325.x

Wisner, J. D. (2003). A structural equation model of supply chain management strategies and firm performance. Journal of Business Logistics, 24 (1), 1-26.

Yu, Y., \& Huo, B. (2018) Supply chain quality integration: relational antecedents and operational consequences. Supply Chain Management: An International Journal, 23 (3), 188-206. https://doi.org/10.1108/SCM-08-2017-0280

\section{APPENDIX}

\section{A.1 Appendix A: Research Measurement Items}

\section{Measurement Items}

Supply Chain Management Practices

Just-in-time Capability

To what extent has this customer and supplier used the following JIT programs with you?
JIT01 Order size reduction
JIT02 Negotiation process simplification
JIT03 Open-order status paperwork reduction
JIT04 Expediting, receiving count, and inspection cost reduction
JIT05 Order lead time reduction
JIT06 Quality assurance program
JIT07 Formal supplier evaluation and selection program 
JIT08 Sole sourcing

Postponement

Please indicate the extent to which you agree or disagree with each of these statements about your company

POS01 Our products are designed for modular assembly

POS02 Our production process modules can be re-arranged so that

POS03 We delay final product assembly activities until customer orders have actually been received

POS04 We delay final product assembly activities until the last possible position (or nearest to customers) in the supply chain

Supply Chain Quality Integration

Internal Quality Integration

Please indicate the extent to which you agree or disagree with each of these statements about your company

IQI01 The functions in our company work well together

IQI02 The functions in our company cooperate to solve conflicts

IQI03 Our company's functions coordinate their activities

IQI04 Our company's functions work interactively with each other

IQI05 During problem solving sessions, we make an effort to get all

team members' opinions and ideas before making a decision

IQI06 Our company forms teams to solve problems

IQI07 In the past 5 years, many problems have been solved through

IQI08 Real-time searching of quality-related operating data

IQI09 The utilization of periodic inter-functional quality meetings among internal functions

Supplier Quality Integration

Please indicate the extent to which you agree or disagree with each of these statements about your company

SQI01 We maintain cooperative relationships with our major supplier

SQI02 We help our major supplier to improve their quality

SQI03 We maintain close communications with our major supplier about quality considerations and design changes

SQI04 Our major supplier provides input into our product development projects for quality control

SQI05 Our major supplier is involved in our new product development processes for quality management

SQI06 We engage our major supplier in our quality improvement efforts

SQI07 We help our major supplier to improve its processes to better meet our quality requirements

SQI08 We share our quality requirements with our major supplier

SQI09 We jointly resolve quality problems with our major supplier

Customer Quality Integration

Please indicate the extent to which you agree or disagree with each of these statements about your company

CQI01 We are frequently in close contact with our major customer in 
CQI02 Our major customer gives us feedback on our quality and delivery performance

CQI03 Our major customer provides input into quality control during our product design process

CQI04 Our processes are certified, or qualified, by our major customer

CQI05 Our major customer is involved in quality management during our new product development process

CQI06 We engage major customer in our quality improvement efforts

\section{Supply Chain Performance}

Supplier Oriented Performance

Please indicate the extent to which you agree or disagree with each of these statements about your company

SOP01 Our major supplier can quickly modify products to meet our company's requirements

SOP02 Our major supplier can quickly introduce new products into the markets

SOP03 Our major supplier can quickly respond to changes in market demand

SOP04 Our supplier has an outstanding on-time delivery record to our company

The supplier's lead time for fulfilling our company's orders

SOP05 (the time which elapses between the receipt of our order and the delivery of the goods) is short

SOP06 Our major supplier provide high level of customer service to our company

Customer Oriented Performance

Please indicate the extent to which you agree or disagree with each of these statements about your company

COP01 Our company can quickly modify products to meet our major customer's requirements

COP02 Our company can quickly introduce new products into the markets

COP03 Our company can quickly respond to changes in market demand

COP04 Our company has an outstanding on-time delivery record to our major customer

The lead time for fulfilling customer orders (the time which

COP05 elapses between the receipt of customer's order and the delivery of the goods) is short

COP06 Our company provides high level of customer service to our major customer

Financial Performance

How does your company perform compared with your major competitors?

FP01 Sales

FP02 Growth in sales

FP03 Profit

FP04 Growth in profit 
FP05 Return on investment (ROI)

FP06 Return on sales (ROS)

FP07 Market share

FP08 Growth in market share

\section{A.2 Appendix B: Item Pengukuran Penelitian}

\begin{tabular}{|c|c|}
\hline & $\begin{array}{l}\text { Item Pengukuran } \\
\text { Ianagement Practices }\end{array}$ \\
\hline Just-in-time & Capability \\
\hline $\begin{array}{l}\text { Sejauh } n \\
\text { program }\end{array}$ & $\begin{array}{l}\text { ana pemasok dan pelanggan anda menerapkan program } \\
\text { ust-in-time }(J I T) \text { berikut bersama anda? }\end{array}$ \\
\hline JIT01 & Pengurangan ukuran pesanan \\
\hline JIT02 & Penyederhanaan proses negosiasi \\
\hline JIT03 & Pengurangan dokumen status open-order \\
\hline JIT04 & $\begin{array}{l}\text { Pengurangan ekspedisi, jumlah penerimaan, dan biaya } \\
\text { pemeriksaan }\end{array}$ \\
\hline JIT05 & Pengurangan lead time pesanan \\
\hline JIT06 & Program jaminan kualitas \\
\hline JIT07 & Program evaluasi dan pemilihan supplier resmi \\
\hline JIT08 & Sumber tunggal \\
\hline Postponeme & \\
\hline $\begin{array}{l}\text { Berdasar } \\
\text { setuju der }\end{array}$ & $\begin{array}{l}\text { an kondisi di perusahaan anda, apakah anda setuju atau tidak } \\
\text { gan pernyataan berikut? }\end{array}$ \\
\hline POS01 & Produk kami telah dirancang untuk perakitan modular \\
\hline POS02 & $\begin{array}{l}\text { Modul proses produksi kami dapat disusun ulang sehingga } \\
\text { proses kustomisasi dapat dilakukan nanti di pusat distribusi }\end{array}$ \\
\hline POS03 & $\begin{array}{l}\text { Kami menunda kegiatan perakitan produk akhir hingga } \\
\text { pesanan pelanggan benar-benar diterima }\end{array}$ \\
\hline POS04 & $\begin{array}{l}\text { Kami menunda proses perakitan produk akhir hingga posisi } \\
\text { akhir yang memungkinkan (atau paling dekat dengan } \\
\text { pelanggan) dalam supply chain }\end{array}$ \\
\hline Supply Chain $\mathrm{C}$ & uality Integration \\
\hline Internal Qua & ity Integration \\
\hline $\begin{array}{l}\text { Berdasar } \\
\text { setuju der }\end{array}$ & $\begin{array}{l}\text { an kondisi di perusahaan anda, apakah anda setuju atau tidak } \\
\text { gan pernyataan berikut? }\end{array}$ \\
\hline IQI01 & Fungsi di perusahaan kami bekerjabersama dengan baik \\
\hline IQI02 & $\begin{array}{l}\text { Fungsi di perusahaan kami bekerjasama untuk menyelesaikan } \\
\text { masalah yang timbul diantara mereka }\end{array}$ \\
\hline IQI03 & $\begin{array}{l}\text { Fungsi di perusahaan kami mengkoordinasikan kegiatan } \\
\text { mereka }\end{array}$ \\
\hline IQI04 & $\begin{array}{l}\text { Fungsi di perusahaan kami bekerja secara interaktif satu } \\
\text { sama lain }\end{array}$ \\
\hline IQI05 & $\begin{array}{l}\text { Selama sesi penyelesaian masalah, kami berusaha } \\
\text { mendapatkan semua opini dan ide semua anggota tim } \\
\text { sebelum membuat keputusan }\end{array}$ \\
\hline IQI06 & Perusahaan kami membentuk tim untuk menyelesaikan \\
\hline
\end{tabular}

DOI: http://dx.doi.org/10.33021/jaaf.v3i2.809 


\begin{tabular}{ll}
\hline masalah \\
IQIam 5 tahun terakhir, banyak masalah yang telah \\
diselesaikan melalui sesi kelompok kecil
\end{tabular} IQI08 $\begin{aligned} & \text { Kualitas terkait pencarian real-time dari data operasi } \\
& \text { Pemanfaatan kualitas pertemuan inter-fungsional berkala } \\
& \text { IQI09 }\end{aligned}$

Supplier Quality Integration

Berdasarkan kondisi di perusahaan anda, apakah anda setuju atau tidak setuju dengan pernyataan berikut? SQI01 Kami mempertahankan hubungan kerjasama dengan supplier

SQI02 Kami membantu supplier kami untuk meningkatkan kualitas mereka

Kami mempertahankan komunikasi yang erat dengan supplier

SQI03 kami mengenai pertimbangan kualitas dan perubahan rancangan

SQI04 Supplier kami memberikan masukan terkait pengembangan produk untuk quality control

SQI05 Supplier kami terlibat dalam proses pengembangan produk baru kami untuk kualitas manajemen

SQI06 Kami melibatkan supplier kami dalam upaya peningkatan kualitas

SQI07 Kami membantu supplier kami untuk meningkatkan prosesnya agar dapat memenuhi persyaratan kualitas kami SQI08 Kami membagikan persyaratan kualitas kami kepada supplier

SQI09 Kami bergabung dengan supplier kami dalam menyelesaikan masalah kualitas

Customer Quality Integration

Berdasarkan kondisi di perusahaan anda, apakah anda setuju atau tidak setuju dengan pernyataan berikut?

CQI01 Dalam manajemen kualitas, kami tetap menjaga hubungan erat dengan pelanggan kami

CQI02 Pelanggan kami memberikan umpan balik mengenai performa kualitas dan pengiriman kami CQI03 Pelanggan kami menyediakan masukan dalam kualitas
kontrol selama proses perancangan produk

CQI04 Proses kami telah bersertifikat, atau memenuhi syarat, dari pelanggan kami

CQI05 Pelanggan kami terlibat dalam manajemen kualitas selama proses pengembangan produk baru kami

CQI06 Kami mengikut-sertakan pelanggan kami dalam upaya

Supply Chain Performance

Supplier Oriented Performance

Berdasarkan kondisi di perusahaan anda, apakah anda setuju atau tidak setuju dengan pernyataan berikut?

SOP01 Supplier kami dapat memodifikasi produk dengan cepat untuk 


\begin{tabular}{cl}
\hline memenuhi persyaratan perusahaan kami \\
SOP02 & $\begin{array}{l}\text { Supplier kami dapat memperkenalkan produk baru kepasar } \\
\text { dengan cepat }\end{array}$ \\
SOP03 & $\begin{array}{l}\text { Supplier kami dapat merespon perubahan dalam permintaan } \\
\text { pasar dengan cepat }\end{array}$ \\
SOP04 & $\begin{array}{l}\text { Supplier kami memiliki rekaman on-time delivery yang luar } \\
\text { biasa ke perusahaan kami } \\
\text { Lead time yang dibutuhkan supplier kami (waktu yang berlalu } \\
\text { antara pemesanan kami dan pengiriman produk) untuk }\end{array}$ \\
SOP06 & $\begin{array}{l}\text { Supplier kami menyediakan layanan pelanggan tingkat tinggi } \\
\text { ke perusahaan kami }\end{array}$ \\
Bustomer Oriented Performance \\
setuju dengan pernyataan berikut? \\
COP01
\end{tabular}

A.3 Appendix B: Reliability, Validity and Multicollinearity Test

\begin{tabular}{lcccccc}
\hline & \multicolumn{2}{c}{ Reliability } & \multicolumn{2}{c}{ Validity } & Collin. \\
& $\rho \mathrm{c}$ & $\mathrm{A}$ & $\mathrm{AVE}$ & Loadings & VIF \\
$\begin{array}{l}\text { Supply Chain } \\
\text { (SCMP) }\end{array}$ & Management & Practices & & & \\
$\begin{array}{l}\text { Just-in-time Cap. } \\
\text { JIT01 }\end{array}$ & 0.914 & 0.900 & 0.582 & & \\
\hline
\end{tabular}




\begin{tabular}{|c|c|c|c|c|c|}
\hline JIT02 & & & & 0.743 & 3.335 \\
\hline JIT03 & & & & 0.832 & 2.649 \\
\hline JIT04 & & & & 0.801 & 4.290 \\
\hline JIT05 & & & & 0.885 & 4.527 \\
\hline JIT06 & & & & 0.841 & 6.917 \\
\hline JIT07 & & & & 0.756 & 5.191 \\
\hline JIT08 & & & & 0.511 & 1.470 \\
\hline Postponement & 0.847 & 0.766 & 0.582 & & \\
\hline POS01 & & & & 0.769 & 1.273 \\
\hline POS02 & & & & 0.729 & 1.534 \\
\hline POS03 & & & & 0.792 & 1.933 \\
\hline POS04 & & & & 0.742 & 1.774 \\
\hline \multicolumn{6}{|c|}{ Supply Chain Quality Integration (SCQI) } \\
\hline Internal Qlt Intgrn & 0.943 & 0.934 & 0.626 & & \\
\hline IQI01 & & & & 0.782 & 5.642 \\
\hline IQI02 & & & & 0.835 & 5.225 \\
\hline IQI03 & & & & 0.720 & 2.356 \\
\hline IQI04 & & & & 0.848 & 8.235 \\
\hline IQI05 & & & & 0.830 & 4.657 \\
\hline IQI06 & & & & 0.828 & 5.063 \\
\hline IQI07 & & & & 0.777 & 3.828 \\
\hline IQI08 & & & & 0.688 & 7.236 \\
\hline IQI09 & & & & 0.718 & 8.014 \\
\hline $\begin{array}{l}\text { Supplier } \\
\text { Intgrn }\end{array}$ & 0.901 & 0.875 & 0.509 & & \\
\hline SQI01 & & & & 0.628 & 4.800 \\
\hline SQI02 & & & & 0.731 & 3.155 \\
\hline SQI03 & & & & 0.712 & 4.329 \\
\hline SQI04 & & & & 0.735 & 3.611 \\
\hline SQI05 & & & & 0.608 & 2.539 \\
\hline SQI06 & & & & 0.851 & 7.728 \\
\hline SQI07 & & & & 0.822 & 8.144 \\
\hline SQI08 & & & & 0.703 & 3.034 \\
\hline SQI09 & & & & 0.541 & 1.921 \\
\hline Customer Qlt Intgrn & 0.897 & 0.869 & 0.509 & & \\
\hline CQI01 & & & & 0.314 & 1.948 \\
\hline CQI02 & & & & 0.346 & 3.261 \\
\hline CQI03 & & & & 0.805 & 4.841 \\
\hline CQI04 & & & & 0.393 & 3.321 \\
\hline CQI05 & & & & 0.774 & 4.611 \\
\hline CQI06 & & & & 0.783 & 2.054 \\
\hline $\begin{array}{l}\text { Supply Chain Per } \\
(S C P)\end{array}$ & rmance & & & & \\
\hline Supplier Orntd Perf. & 0.911 & 0.920 & 0.634 & & \\
\hline SOP01 & & & & 0.682 & 1.988 \\
\hline SOP02 & & & & 0.840 & 2.857 \\
\hline SOP03 & & & & 0.914 & 4.565 \\
\hline SOP04 & & & & 0.703 & 1.772 \\
\hline
\end{tabular}




\begin{tabular}{|c|c|c|c|c|c|}
\hline SOP05 & & & & 0.818 & 4.056 \\
\hline SOP06 & & & & 0.819 & 3.434 \\
\hline Customer Orntd Perf. & 0.920 & 0.894 & 0.661 & & \\
\hline COP01 & & & & 0.656 & 2.081 \\
\hline COP02 & & & & 0.744 & 2.164 \\
\hline COP03 & & & & 0.953 & 9.039 \\
\hline COP04 & & & & 0.759 & 2.688 \\
\hline COP05 & & & & 0.932 & 8.325 \\
\hline COP06 & & & & 0.800 & 2.401 \\
\hline $\begin{array}{l}\text { Financial } \\
\text { Perform. }\end{array}$ & 0.960 & 0.955 & 0.729 & & \\
\hline FP01 & & & & 0.793 & 4.191 \\
\hline FP02 & & & & 0.728 & 3.719 \\
\hline FP03 & & & & 0.842 & 8.352 \\
\hline FP04 & & & & 0.771 & 5.238 \\
\hline FP05 & & & & 0.912 & 7.847 \\
\hline FP06 & & & & 0.921 & 7.211 \\
\hline FP07 & & & & 0.880 & 8.555 \\
\hline FP08 & & & & 0.893 & 7.706 \\
\hline
\end{tabular}

\section{A.4 Appendix C: Cross Loadings Factor}

\begin{tabular}{ccccccccc}
\hline & JIT & POS & IQI & SQI & CQI & SOP & COP & FP \\
\hline JIT01 & 0.660 & 0.303 & 0.203 & 0.152 & 0.163 & 0.447 & 0.257 & 0.148 \\
JIT02 & 0.811 & 0.098 & 0.314 & 0.356 & 0.435 & 0.365 & 0.217 & -0.080 \\
JIT03 & 0.828 & 0.337 & 0.288 & 0.447 & 0.434 & 0.548 & 0.389 & 0.160 \\
JIT04 & 0.675 & 0.245 & 0.078 & 0.161 & 0.129 & 0.570 & 0.295 & 0.119 \\
JIT05 & 0.844 & 0.168 & 0.185 & 0.252 & 0.203 & 0.568 & 0.404 & 0.224 \\
JIT06 & 0.917 & 0.212 & 0.462 & 0.545 & 0.410 & 0.505 & 0.419 & 0.191 \\
JIT07 & 0.851 & 0.146 & 0.496 & 0.572 & 0.363 & 0.473 & 0.425 & 0.218 \\
JIT08 & 0.379 & 0.375 & 0.046 & 0.005 & 0.271 & 0.312 & 0.365 & 0.172 \\
POS01 & 0.371 & 0.668 & 0.194 & 0.199 & 0.387 & 0.431 & 0.588 & 0.323 \\
POS02 & 0.210 & 0.714 & 0.119 & 0.042 & 0.267 & 0.301 & 0.309 & -0.034 \\
POS03 & 0.154 & 0.852 & 0.102 & 0.226 & 0.409 & 0.335 & 0.218 & 0.086 \\
POS04 & 0.083 & 0.799 & 0.124 & 0.210 & 0.430 & 0.421 & 0.337 & 0.027 \\
IQI01 & 0.235 & -0.009 & 0.775 & 0.597 & 0.236 & 0.222 & 0.307 & 0.609 \\
IQI02 & 0.285 & 0.106 & 0.830 & 0.616 & 0.353 & 0.157 & 0.380 & 0.572 \\
IQI03 & 0.633 & 0.272 & 0.761 & 0.765 & 0.583 & 0.747 & 0.719 & 0.260 \\
IQI04 & 0.336 & 0.039 & 0.838 & 0.632 & 0.359 & 0.204 & 0.394 & 0.628 \\
IQI05 & 0.207 & -0.191 & 0.791 & 0.521 & 0.162 & 0.147 & 0.327 & 0.651 \\
IQI06 & 0.235 & 0.046 & 0.819 & 0.606 & 0.301 & 0.197 & 0.331 & 0.494 \\
IQI07 & 0.105 & 0.048 & 0.753 & 0.537 & 0.258 & 0.228 & 0.265 & 0.486 \\
IQI08 & 0.303 & 0.334 & 0.701 & 0.602 & 0.583 & 0.498 & 0.811 & 0.309 \\
IQI09 & 0.286 & 0.312 & 0.741 & 0.751 & 0.697 & 0.540 & 0.770 & 0.315 \\
SQI01 & 0.072 & -0.068 & 0.568 & 0.542 & 0.269 & 0.275 & 0.344 & 0.660 \\
SQI02 & 0.260 & 0.032 & 0.736 & 0.697 & 0.357 & 0.197 & 0.311 & 0.582 \\
SQI03 & 0.151 & -0.092 & 0.525 & 0.635 & 0.295 & 0.390 & 0.418 & 0.638 \\
SQI04 & 0.448 & 0.198 & 0.601 & 0.780 & 0.594 & 0.569 & 0.490 & 0.172 \\
SQI05 & 0.387 & 0.425 & 0.479 & 0.669 & 0.649 & 0.468 & 0.402 & 0.026 \\
\hline
\end{tabular}




\begin{tabular}{lllllllll}
\hline SQI06 & 0.477 & 0.223 & 0.692 & 0.888 & 0.637 & 0.633 & 0.538 & 0.196 \\
SQI07 & 0.542 & 0.247 & 0.734 & 0.849 & 0.594 & 0.611 & 0.652 & 0.306 \\
SQI08 & 0.464 & 0.306 & 0.587 & 0.733 & 0.708 & 0.492 & 0.817 & 0.192 \\
SQI09 & 0.253 & 0.207 & 0.335 & 0.545 & 0.500 & 0.241 & 0.293 & 0.318 \\
CQI01 & 0.061 & -0.233 & 0.477 & 0.448 & 0.249 & 0.208 & 0.343 & 0.558 \\
CQI02 & 0.293 & -0.284 & 0.620 & 0.504 & 0.297 & 0.047 & 0.231 & 0.442 \\
CQI03 & 0.307 & 0.426 & 0.322 & 0.533 & 0.886 & 0.372 & 0.510 & -0.044 \\
CQI04 & 0.204 & -0.107 & 0.586 & 0.531 & 0.295 & 0.194 & 0.222 & 0.468 \\
CQI05 & 0.361 & 0.657 & 0.328 & 0.544 & 0.862 & 0.461 & 0.435 & -0.015 \\
CQI06 & 0.391 & 0.517 & 0.412 & 0.539 & 0.846 & 0.388 & 0.547 & -0.051 \\
SOP01 & 0.286 & 0.484 & 0.268 & 0.470 & 0.472 & 0.705 & 0.532 & 0.197 \\
SOP02 & 0.513 & 0.511 & 0.306 & 0.457 & 0.374 & 0.824 & 0.431 & 0.225 \\
SOP03 & 0.504 & 0.340 & 0.483 & 0.531 & 0.391 & 0.905 & 0.591 & 0.292 \\
SOP04 & 0.385 & 0.269 & 0.138 & 0.199 & 0.075 & 0.648 & 0.376 & 0.069 \\
SOP05 & 0.559 & 0.368 & 0.400 & 0.451 & 0.300 & 0.812 & 0.609 & 0.367 \\
SOP06 & 0.559 & 0.374 & 0.526 & 0.693 & 0.489 & 0.854 & 0.628 & 0.349 \\
COP01 & 0.259 & 0.326 & 0.529 & 0.480 & 0.466 & 0.242 & 0.694 & 0.561 \\
COP02 & 0.371 & 0.389 & 0.396 & 0.396 & 0.257 & 0.682 & 0.691 & 0.257 \\
COP03 & 0.445 & 0.554 & 0.614 & 0.632 & 0.613 & 0.714 & 0.956 & 0.438 \\
COP04 & 0.329 & 0.402 & 0.546 & 0.531 & 0.344 & 0.703 & 0.725 & 0.370 \\
COP05 & 0.413 & 0.360 & 0.656 & 0.659 & 0.599 & 0.585 & 0.946 & 0.423 \\
COP06 & 0.360 & 0.317 & 0.524 & 0.598 & 0.586 & 0.453 & 0.823 & 0.237 \\
FP01 & 0.292 & 0.222 & 0.746 & 0.619 & 0.289 & 0.342 & 0.440 & 0.839 \\
FP02 & 0.036 & 0.114 & 0.501 & 0.344 & 0.098 & 0.213 & 0.461 & 0.817 \\
FP03 & 0.152 & 0.089 & 0.596 & 0.445 & 0.174 & 0.269 & 0.521 & 0.919 \\
FP04 & 0.037 & -0.012 & 0.566 & 0.438 & 0.054 & 0.271 & 0.401 & 0.868 \\
FP05 & 0.118 & 0.175 & 0.241 & 0.220 & 0.023 & 0.272 & 0.343 & 0.842 \\
FP06 & 0.222 & 0.234 & 0.374 & 0.289 & 0.049 & 0.370 & 0.294 & 0.834 \\
FP07 & 0.179 & 0.057 & 0.182 & 0.071 & -0.179 & 0.237 & 0.246 & 0.796 \\
FP08 & 0.147 & 0.152 & 0.287 & 0.275 & 0.038 & 0.293 & 0.323 & 0.817 \\
\hline
\end{tabular}

\section{A.5 Appendix D: Structural Equation Modelling}

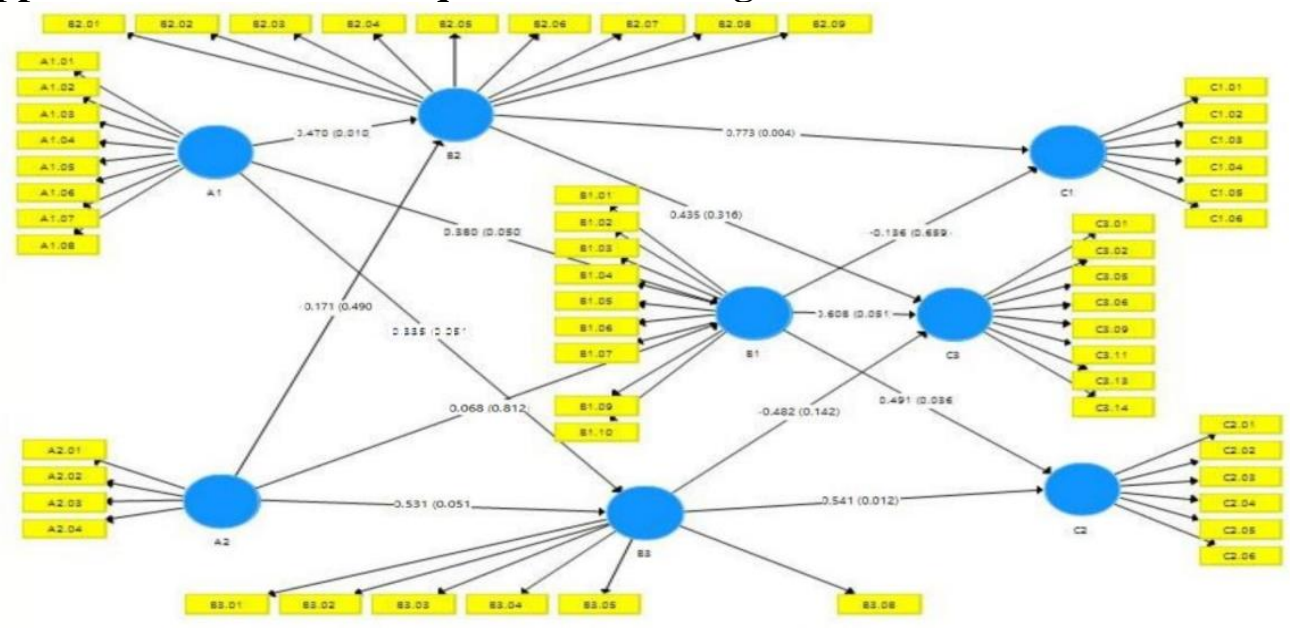

Source: SmartPLS 3.2.8 


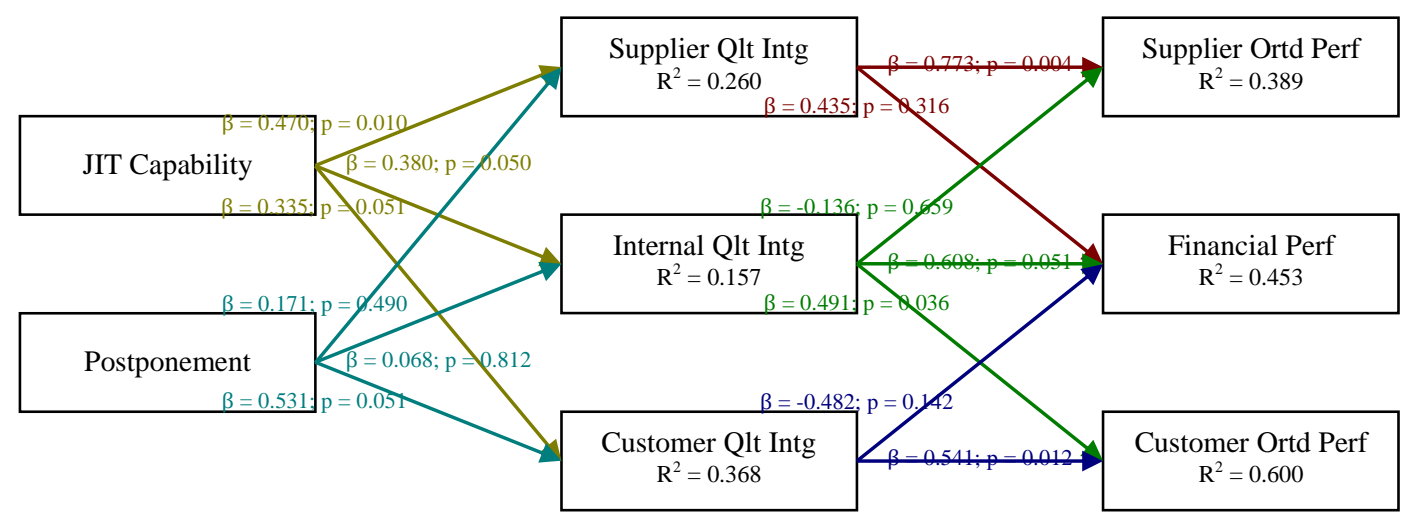

Structural equation modelling for the effect of Supply Chain Management Practices (SCMP) to Supply Chain Quality Integration (SCQI) and Supply Chain Quality Integration (SCQI) to Supply Chain Performances (SCP)
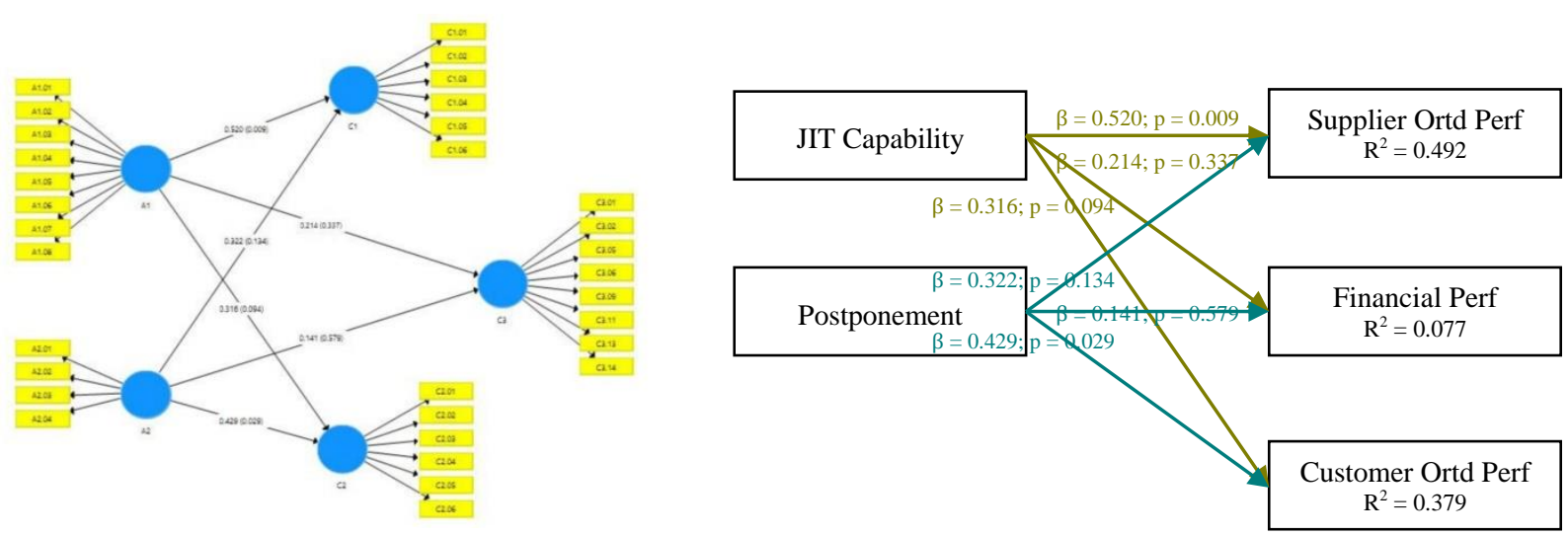

Source: SmartPLS 3.2.8

Structural equation modelling for the direct effect of Supply Chain Management Practices (SCMP) to Supply Chain Performances (SCP)

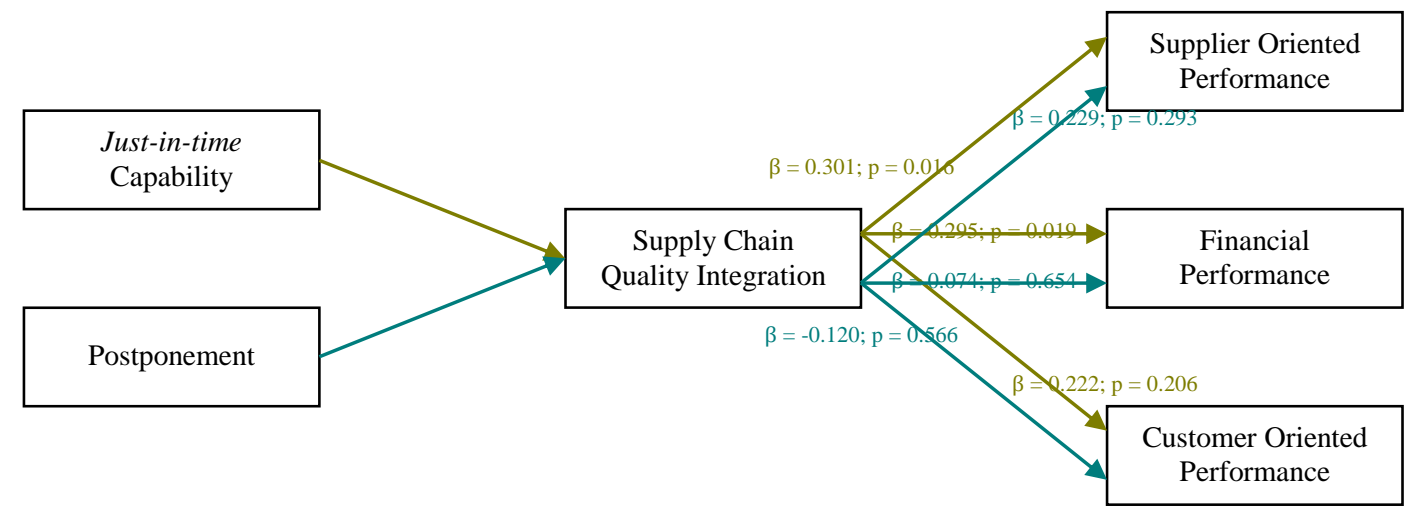

Structural equation modelling for the indirect effect of Supply Chain Quality Integration (SCQI) to the effect of Supply Chain Management Practices (SCMP) to Supply Chain Performances (SCP) 